\title{
Clinical Evaluation of Panchavaktra Ras in the Management of Amavata (Rheumatoid Arthritis)
}

\section{Research Article}

\author{
Srinivasulu Bandari ${ }^{1}$, Bhadra Dev $\mathbf{P}^{2}$, Murthy P H C \\ ${ }^{*}{ }^{1}$ P.G.Scholar, ${ }^{2}$ Supervisor, Professor \& Head, ${ }^{3}$ Co-Supervisor, Gazetted-Lecturer, P.G. \\ Dept. of Rasa-Shastra, Dr.N.R.S.Govt. Ayurvedic College, Vijayawada, Andhra Pradesh
}

\begin{abstract}
Objectives: This study was conducted to evaluate the effectiveness of Panchavaktra Ras in the Management of Amavata (Rheumatoid Arthritis). Materials and Methods: A single blind clinical trial was conducted at Dr. Achanta Lakshmipati Govt. Ayurvedic Hospital, M.G. Road, Vijayawada. 50 patients were selected and trial drug was advocated in a dose of $300 \mathrm{mg}$. (2 tablets) twice a day with Trikatu and Arka moola twak kashaya as anupana. Treatment was given for 45 days with the result assessment recorded at every 15 days. Subjective and objective parameters were analyzed before and after the treatment. In subjective parameters Sandhi Shula, Jadya, Angamarda, Alasya, Agnimandhya and Vidvibandha are taken, while Sandhi Shotha, Erythrocyte Sedimentation Rate (ESR) and R.A. Factor are considered as objective parameters. Results: It was observed that $48 \%$ were in mild relief group, while $50 \%$ were of moderate relief and there was Good relief in $2 \%$ of patients. Both Subjective and Objective parameters have been analyzed statistically. The relief of Sandhi Shula, Stabdata, Angimandya, Angamarda, Alasya and Vidvibandha found highly significant $(\mathrm{P}<0.001)$ and same results in reduction Sandhi Shotha, ESR levels and RA Factor. Conclusion: Panchavaktra Ras prepared as per the textual standards is highly effective in Amavata and showing a way out to the individual suffering from this chronic disease. The study confirmed the effect of trial drug in Amavata (Rheumatoid arthritis) in improving the quality of life of patients without any untoward effects.
\end{abstract}

Key wards: Panchavaktra Ras, Herbo-mineral formulation, Amavata, Rheumatoid Arthritis

\section{Introduction:}

Panchavaktra Ras is being a herbomineral formulation with a unique combination of ingredients that have a direct effect on the etiopathogenesis of Amavata. The pharmacological actions of each of the ingredient also go in

*Corresponding Author:

Dr. Bandari Srinivasulu

Consultant (Ayurveda)

National institute of Indian Medical

Heritage,

Osmania Medical College building

Putlibowli, Hyderabad.

E.mail: dr.vaasu@ rediffmail.com

Ph.No: 09347000599 accordance with the line of treatment that has been described in Ayurvedic classics.

Madhava emphasizes that it is a systemic disorder where digestive and metabolic mechanism are involved. Ama (indigested food), in its abnormal form circulates throughout the body and vitiated by three of the Doshas, leading to considerable impairment of body movements (1). Madhava clarifies that Amavata is not simply a joint inflammation, but a constitutional disorder involving whole body. Arthritis is one of its main features. Other symptoms of Amavata are body ache, anorexia, thirst, nausea, lassitude, heaviness of the body, 
fever, indigestion and feeling of hollowness of the limbs (2).

Material and Methods:

A) Preparation of Panchavaktra ras

B) Selection of Patients

C) Dose and Administration

D) Criteria for Selection

E) Laboratory Investigation

F) Parameters for Assessment

G) Results of the Treatment

\section{A) Preparation of Panchavaktra ras}

Panchavaktra ras consists of equal parts of

1. Purified Parada (3) (Mercury)

2. Purified Gandhaka (4) (Sulphur)

3. Purified Tankana (5) (Borax)

4. Barjita Pippali (dried fruit of Piper longum)

5. Barjita Marica (dried fruit of Piper nigrum)

6. Bavana (maceration) with the leaf juice of Krshna Dhattura (Black coloured leaf of Datura metel).

Panchavaktra ras was a Khalviya rasayana which was mentioned in the classical text of Bhasavarajiyam $6^{\text {th }}$ chapter of Vataroga nidana lakshana cikitsa adhyaya (6) and indicated for the Amavata (Rheumatoid arthritis). The ingredients numbers 1 to 3 were purified with the authentic method. The ingredients number 4 and 5 were fried in an earthen pan on a mild flame and powdered individually and passed through 80\# sieve. At first Kajjali (black sulphide of mercury) was prepared with equal parts of purified Parada and Gandhaka in Khalva Yantra (mortar pestle apparatus). All the ingredients were mixed thoroughly in specified ratio (1 part each) and ground in the Khalva Yantra with the leaf juice of Krishna Dhattura to obtain a homogeneous blend. The blended mass was dried in shade. Then added starch, binding agents and lubricants according to the drug quantity and made tablets through the punch machine. The rolled tablets were dried in a tray dryer at a temperature not exceeding $60^{\circ} \mathrm{C}$. It was packed in a tightly closed glass containers for further use. The final product of Panchavaktra ras was found to be a dark gray coloured. Three samples were prepared in the same method as mentioned above in three different seasons. (Figure no $4 \& 5$ )

\section{B) Selection of Patients}

50 cases of diagnosed Amavata (based on Ayurvedic texts and clinical features) in which 30 were males and 20 were females between the age of 10 and 70 years. All patients were subjected to detailed history, clinical examination and laboratory investigations before and after treatment. Clinical features and laboratory investigations viz., E.S.R, R.A. Factor, routine urine examinations were taken as criteria for assessment of results.

\section{C) Dose and Administration}

$300 \mathrm{mg}$. (2 tablets) twice a day with Trikatu and Arka moola twak kashaya (decoction prepared with root bark of Calotropis gigantea (L.) R.BR.) as anupana (drink taken after medicine). Treatment was given for 45 days with the result assessment recorded at every 15 days.

\section{D) Criteria for Selection Criteria of Inclusion:}

1. Age between 10 years to 70 years

2. Chronicity upto 5 years Criteria of Exclusion:

1. Age below 10 and above 70 years

2. Gout and osteoarthritis

3. Arthritis with malignancy

4. Arthritis with other systemic diseases

\section{E) Laboratory Investigation}

For the purpose of diagnosis, assessment of disease severity, assessment of general health status and clinical improvement, certain routine and specific laboratory investigations were performed in the Dr. Achanta Lakshmipati Govt. Ayurvedic Hospital, Vijayawada. 


\section{A. Haematological:}

Hemoglobin percentage

Erythrocyte Sedimentation Rate (ESR)

Total leucocytes count

Differential Count

B. Biochemical:

C - Reactive Protein

A.S.O. Titre

C. Immunological:

Rheumatoid Factor

F) Parameters for Assessment

Subjective Parameters:
1. Sandhi Shula
2. Jadya
3. Angamarda
4. Alasya
5. Agnimandya
6. Vidvibandha

\section{Objective Parameters:}

7. Sandhi Shotha

8. E.S.R

9. R.A. Factor

Parameter with gradation

Score

I. Sandhi Shula (Joint Pain)

No pain $\quad-0$

Pain at the beginning of - 5

physical activity

Pain hampering the physical - 10 activity

Pain permanently present - 15

during physical activity

Pain present even at rest

$-20$

II. Sandhi Shotha (Joint

Swelling)

Absent $\quad-0$

Mild swelling covering the - 3

bony prominence of joint

The bony prominence of joint - 5

swelling completely

Covering the joint capsule $\quad-10$

Deformity in the joint $\quad-15$

III. Stabdhata or Jadya

(Morning Stiffness)

Absent

$-0$

Stiffness for 15 minutes

$-5$

Stiffness for 15-30 minutes $\quad-10$

Stiffness more than 30 minutes $\quad-15$
IV. Angamarda (Body pains)

Absent $\quad-0$

Mild body pains $\quad-3$

Superficial to deep muscle pain - 5

Muscle with Bony pains $\quad-7$

Severe body pains $\quad-10$

V. Alasya (Laziness)

Absent $\quad-0$

Unwillingness to physical - 5

exercise

Desire to sit all the time $\quad-7$

Desire to lie down all the time $\quad-10$

VI. Agnimandhya

(Indigestion)

Absent $\quad-0$

Transiently present, no -1

associated symptoms

Present for long period, less - 3

associated symptoms

Regular presence with much - 5

associated symptoms

VII.

Vidvibandha

(Constipation)

No constipation $\quad-0$

Mildness, daily with straining $\quad-1$

Once in 2 days with mild - 3

straining

Once in 2 days with severe - 5

straining

VIII. E.S.R

Normal $\quad-0$

Mild, 21-30 mm/hour $\quad-3$

Moderate, 30-40 - 5

Severe, $41 \mathrm{~mm} /$ hour and above $\quad-10$

IX. R. A. Factor

Negative $\quad-0$

Positive $\quad-10$

\section{G) Results of the Treatment}

Score systems have evolved for gradation of severity in disease and results of treatment were assessed on the basis of improvement in gradation of severity and classified as follows:

- Good response: When the sign and symptoms are relieved about $75 \%$ and above. 
- Moderate response: When the sign and symptoms are relieved about $51 \%$ to $75 \%$

- Mild response: When the sign and symptoms are relieved about $26 \%$ to $50 \%$

\section{Observation and Results:}

The different data collected and study observations are presented as follows:

\section{General observations:}

Table No. 1: Age and sex wise distribution of 50 Amavata patients

\begin{tabular}{|l|l|l|l|l|c|c|l|}
\hline S.No & Age (In years.) & \multicolumn{2}{|l|}{ Male } & \multicolumn{2}{l|}{ Female } & \multicolumn{2}{|c|}{ Total } \\
\hline & & No & $\%$ & No & $\%$ & No & $\%$ \\
\hline & $10-20$ & 2 & 4 & 1 & 2 & 3 & 6 \\
\hline & $21-30$ & 4 & 8 & 5 & 10 & 9 & 18 \\
\hline & $31-40$ & 6 & 12 & 11 & 22 & 17 & 34 \\
\hline & $41-50$ & 2 & 4 & 6 & 12 & 8 & 16 \\
\hline & $51-60$ & 3 & 6 & 5 & 10 & 8 & 16 \\
\hline & $61-70$ & 3 & 6 & 2 & 4 & 5 & 10 \\
\hline & Total & 20 & 40 & 30 & 60 & 50 & 100 \\
\hline
\end{tabular}

It was observed that, out of 50 patients 20 were male and 30 were female. Incidence of disease is found more common in females than males (40\%: 60\%). Out of maximum number of patients, 34\% were from the age group of 31-40 years followed by $18 \%$ in $21-30$ years age group and $16 \%$ of patients were found in the age of 41-50 and 51-60 years age group respectively.

Table No. 2: Symptoms wise observation of 50 patients of Amavata

\begin{tabular}{|l|l|l|l|}
\hline S.No & Main Symptoms & No. of patients & Percentage \\
\hline & Sandhi Shula & 50 & 100.00 \\
\hline & Sandhi Shotha & 45 & 90 \\
\hline & Agnimandya & 42 & 84 \\
\hline & Vrschika Danshvat Pida & 28 & 56 \\
\hline & Angamarda & 50 & 100 \\
\hline & Jadya & 43 & 86 \\
\hline & Alasya & 44 & 88 \\
\hline & Vidvibandha & 31 & 62 \\
\hline & Associated symptoms & & \\
\hline & Aruchi & 26 & 52 \\
\hline & Trishna & 22 & 44 \\
\hline & Utsahahani & 36 & 72 \\
\hline & Gaurava & 28 & 56 \\
\hline & Jwara & 15 & 30 \\
\hline & Apaka & 14 & 28 \\
\hline & Praseka & 12 & 24 \\
\hline & Daha & 13 & 26 \\
\hline & Bahumootrata & 24 & 48 \\
\hline & Kukshi Sula & 08 & 16 \\
\hline & Nidraviparyaya & 24 & 48 \\
\hline
\end{tabular}




\begin{tabular}{|l|l|l|l|}
\hline & Chardi & 2 & 4 \\
\hline & Bhrama & 4 & 8 \\
\hline & Murcha & 0 & 0 \\
\hline & Hridgraha & 4 & 8 \\
\hline & Antrakujana & 18 & 36 \\
\hline & Anaha & 28 & 56 \\
\hline
\end{tabular}

It was observed that cardinal symptoms like Sandhi Shula100\%, Sandhi Shotha 90\%, Angamarda 100\%, Agnimandya in 84\%, Alasya in 88\%, Jadya in 86\%, Vidvibandha 62\%, Vrschika danshavat pida in 56\% was observed in patients (As shown in Graph no. 10).

\section{Results:}

Subjective Parameters:

Table No. 3: Assessment of results in Subjective parameters (Sandhi Shula)

\begin{tabular}{|l|l|l|l|}
\hline S. No & Result & No. Patients & Percentage \\
\hline 1. & Good response (75\% or above) & 4 & 8 \\
\hline 2. & Moderate response (51-75\%) & 18 & 36 \\
\hline 3. & Mild response $(26-50 \%)$ & 19 & 38 \\
\hline 4. & No response $(0-25 \%)$ & 09 & 18 \\
\hline
\end{tabular}

Good response was observed in $8 \%$ of patients, Moderate response was observed in $36 \%$ of patients, Mild improvement was observed in $38 \%$ of patients, while there was no improvement in $18 \%$ of patients (As shown in Graph no. 1).

Table No. 4: Assessment of results in Subjective parameters (Jadya)

\begin{tabular}{|l|l|l|l|}
\hline S. No & Result & No. Patients & Percentage \\
\hline 1. & Good response $(75 \%$ or above) & 12 & 27.91 \\
\hline 2. & Moderate response $(51-75 \%)$ & 01 & 2.33 \\
\hline 3. & Mild response $(26-50 \%)$ & 24 & 55.81 \\
\hline 4. & No response $(0-25 \%)$ & 06 & 13.95 \\
\hline
\end{tabular}

Good response was observed in $27.91 \%$ of patients, Moderate response was observed in $2.23 \%$ of patients, Mild improvement was observed in $55.81 \%$ of patients, while there was no improvement in $13.95 \%$ of patients (As shown in Graph no. 2).

Table No. 5: Assessment of results in Subjective parameters (Angamarda)

\begin{tabular}{|l|l|l|l|}
\hline S. No & Result & No. Patients & Percentage \\
\hline 1. & Good response (75\% or above) & 09 & 18 \\
\hline 2. & Moderate response (51-75\%) & 07 & 14 \\
\hline 3. & Mild response (26-50\%) & 30 & 60 \\
\hline 4. & No response $(0-25 \%)$ & 04 & 08 \\
\hline
\end{tabular}

Good response was observed in $18 \%$ of patients, Moderate response was observed in $14 \%$ patients, Mild improvement was observed in $60 \%$ of patients, while there was no improvement in $08 \%$ of patients (As shown in Graph no. 3).

Table No. 6: Assessment of results in Subjective parameters (Alasya)

\begin{tabular}{|l|l|l|l|}
\hline S. No & Result & No. Patients & Percentage \\
\hline
\end{tabular}




\begin{tabular}{|l|l|l|l|}
\hline 1. & Good response (75\% or above) & 17 & 38.64 \\
\hline 2. & Moderate response $(51-75 \%)$ & 17 & 38.64 \\
\hline 3. & Mild response $(26-50 \%)$ & 10 & 22.73 \\
\hline 4. & No response $(0-25 \%)$ & 00 & 00 \\
\hline
\end{tabular}

Good response was observed in $38.64 \%$ of patients, Moderate response was observed 38.64 of patients, Mild improvement was observed in $22.73 \%$ of patients (As shown in Graph no. 4).

Table No. 7: Assessment of results in Subjective parameters (Agnimandya)

\begin{tabular}{|l|l|l|l|}
\hline S. No & Result & No. Patients & Percentage \\
\hline 1. & Good response (75\% or above) & 14 & 31.82 \\
\hline 2. & Moderate response $(51-75 \%)$ & 00 & 00 \\
\hline 3. & Mild response $(26-50 \%)$ & 26 & 61.9 \\
\hline 4. & No response $(0-25 \%)$ & 02 & 4.76 \\
\hline
\end{tabular}

Good response was observed in $31.82 \%$ of patients, Mild improvement was observed in $61.9 \%$ of patients, while there was no improvement in $4.76 \%$ of patients (As shown in Graph no. 5).

Table No. 8: Assessment of results in Subjective parameters (Vidvibandha)

\begin{tabular}{|l|l|l|l|}
\hline S. No & Result & No. Patients & Percentage \\
\hline 1. & Good response (75\% or above) & 35 & 77.55 \\
\hline 2. & Moderate response $(51-75 \%)$ & 00 & 00 \\
\hline 3. & Mild response $(26-50 \%)$ & 07 & 15.91 \\
\hline 4. & No response $(0-25 \%)$ & 02 & 4.56 \\
\hline
\end{tabular}

Good response was observed in $77.55 \%$ of patients, Mild improvement was observed in $15.91 \%$ of patients, while there was no improvement in $4.56 \%$ of patients (As shown in Graph no. 6).

Table No. 9: Assessment of results in all the Subjective parameters

\begin{tabular}{|l|l|l|l|}
\hline S. No & Result & No. Patients & Percentage \\
\hline 1. & Good response (75\% or above) & 1 & 2 \\
\hline 2. & Moderate response (51-75\%) & 25 & 50 \\
\hline 3. & Mild response (26-50\%) & 24 & 48 \\
\hline 4. & No response (0-25\%) & 0 & 00 \\
\hline
\end{tabular}

Among the 50 cases treated with Panchavaktra Ras, 01 (2.00\%) cases got Good response, $25(50 \%)$ cases got Moderate response and 24 (48\%) cases got mild response (As shown in Graph no. 11).

Objective Parameters:

Table No. 10: Assessment of results in Objective parameters (Sandhi Shotha)

\begin{tabular}{|l|l|l|l|}
\hline S. No & Result & No. Patients & Percentage \\
\hline 1. & Good response (75\% or above) & 8 & 16 \\
\hline 2. & Moderate response $(51-75 \%)$ & 17 & 34 \\
\hline 3. & Mild response $(26-50 \%)$ & 11 & 22 \\
\hline 4. & No response $(0-25 \%)$ & 06 & 12 \\
\hline
\end{tabular}


Good response was observed in $16 \%$ of patients, Moderate response was observed in $34 \%$ of patients, Mild response was observed in $22 \%$ of patients, while there was no improvement in $12 \%$ of patients (Figure no. $1,2 \& 3$ ) (As shown in Graph no. 7).

Table No. 11: Assessment result in Objective parameter E.S.R

\begin{tabular}{|l|l|l|l|}
\hline S. No & Result & No. Patients & Percentage \\
\hline 1. & Good response (75\% or above) & 13 & 26 \\
\hline 2. & Moderate response $(51-75 \%)$ & 15 & 30 \\
\hline 3. & Mild response $(26-50 \%)$ & 11 & 22 \\
\hline 4. & No response $(0-25 \%)$ & 11 & 22 \\
\hline
\end{tabular}

Good response was observed in $26 \%$ of patients, Moderate response was observed in $30 \%$ of patients, Mild improvement was observed in $22 \%$ of patients, while there was no improvement in $11 \%$ of patients (As shown in Graph no. 8).

Table No. 12: Assessment of results in Objective parameters (R.A Factor)

\begin{tabular}{|l|l|l|l|l|}
\hline \multirow{2}{*}{ S. No } & R. A. Factor & No. & of & Percentage \\
\cline { 2 - 3 } & Before & After & 29 & \\
\hline 1. & Positive & Positive & 29 & 58 \\
\hline 2. & Positive & Negative & 07 & 14 \\
\hline 3. & Negative & Positive & 00 & 00 \\
\hline 4. & Negative & Negative & 14 & 28 \\
\hline
\end{tabular}

By considering RA factor, it was static in $58 \%$ of the patients, i.e., positive before and after treatment, $28 \%$ negative before and after treatment, while $14 \%$ of the patients have shown negative in RA factor after the complete course of treatment (As shown in Graph no. 9).

Table No. 13: Showing total percentage of relief in "Amavata"

\begin{tabular}{|l|l|l|l|l|}
\hline $\begin{array}{c}\text { S. } \\
\text { No }\end{array}$ & Parameter & BT & \multicolumn{1}{c|}{ AT } & \% \\
\hline 1. & Sandhi Shula & 630 & 340 & 46 \\
\hline 2. & Sandhi Shotha & 350 & 151 & 56 \\
\hline 3. & Jadya & 440 & 160 & 63 \\
\hline 4. & Angamarda & 420 & 171 & 59 \\
\hline 5. & Alasya & 326 & 135 & 58 \\
\hline 6. & Agnimandya & 102 & 28 & 72 \\
\hline 7. & Vidvibanda & 58 & 9 & 84 \\
\hline 8. & ESR & 369 & 146 & 60 \\
\hline 9. & RA Factor & 360 & 290 & 20 \\
\hline & & &
\end{tabular}

As per the percentage of relief of symptoms, the basis of the total score before and after treatment, Vidvibandha was the highest percent relief i.e., $84 \%$, followed by $63 \%$ in Jiadya, 46\% in Sandhi Shula, 60\% in ESR, 59\% in Agnimandya, 58\% in Alasya, 56\% in Sandhi Shotha and 20\% in R.A. factor (As shown in Graph no. 12). 
Table No. 14: Statistical analysis on overall parameters $[\mathbf{N}=\mathbf{5 0}]$

\begin{tabular}{|l|l|l|l|l|l|l|l|}
\hline & BT & AT-1 & D-1 & AT-2 & D-2 & AT-3 & D-3 \\
\hline M.G.S. & 60.02 & 58.36 & 1.66 & 44.90 & 15.12 & 28.60 & 31.42 \\
\hline S.D. & \pm 48.951 & \pm 47.675 & \pm 2.656 & \pm 36.420 & \pm 13.929 & \pm 23.770 & \pm 26.853 \\
\hline S.E. & 6.923 & 6.742 & 0.376 & 5.151 & 1.970 & 3.362 & 3.798 \\
\hline t & & & 4.419 & & 7.676 & & 8.274 \\
\hline P & & & $<0.001$ & & $<0.001$ & & $<0.001$ \\
\hline
\end{tabular}

Based on the numerical score, statistical analysis was also done on overall parameters. The mean difference on relief of overall parameters when compared with student's paired ' $t$ ' test before and after treatment was found highly significant $(\mathrm{P}>0.001)$ at every subsequent assessment i.e. after 15, 30 and 45 days.

Table No. 15: Statistical analysis on relief of Sandhi Shula $[\mathrm{N}=50]$

\begin{tabular}{|l|l|l|l|l|l|l|l|}
\hline & BT & AT-1 & D-1 & AT-2 & D-2 & AT-3 & D-3 \\
\hline M.G.S. & 12.60 & 12.30 & 0.30 & 10.20 & 2.40 & 6.80 & 5.80 \\
\hline S.D. & \pm 2.8997 & \pm 2.8944 & \pm 1.1995 & \pm 3.4934 & \pm 2.5234 & \pm 3.4641 & \pm 2.3387 \\
\hline S.E. & 0.410 & 0.409 & 0.170 & 0.494 & 0.357 & 0.490 & 0.331 \\
\hline t & & & 1.769 & & 6.725 & & 17.537 \\
\hline P & & & $>0.05$ & & $<0.001$ & & $<0.001$ \\
\hline
\end{tabular}

The most predominant subjective symptom Sandhi Shula measured before and every after subsequent assessment, the mean difference of before and after treatment in relief of Joint pain was found highly significant $(\mathrm{P}>0.001)$ on each subsequent assessment of the result i.e. after 15,30 and 45 days.

Table No. 16: Statistical analysis on relief of Sandhi Shotha $[\mathrm{N}=45]$

\begin{tabular}{|l|l|l|l|l|l|l|l|}
\hline & BT & AT-1 & D-1 & AT-2 & D-2 & AT-3 & D-3 \\
\hline M.G.S. & 6.932 & 6.818 & 0.114 & 5.159 & 1.773 & 3.432 & 3.500 \\
\hline S.D. & \pm 2.6577 & \pm 2.6309 & \pm 1.3006 & \pm 1.7830 & \pm 2.2750 & \pm 2.4064 & \pm 2.3789 \\
\hline S.E. & 0.396 & 0.392 & 0.194 & 0.266 & 0.339 & 0.359 & 0.355 \\
\hline t & & & 0.586 & & 5.227 & & 9.870 \\
\hline P & & & $>0.05$ & & $<0.001$ & & $<0.001$ \\
\hline
\end{tabular}

The objective parameter Sandhi Shotha means difference on reduction of swelling on comparison before and after treatment was not significant $(\mathrm{P}>0.05)$ at first assessment i.e. after 15 days of the treatment, but found highly significant reduction of swelling $(\mathrm{P}<0.001)$ at second and third assessments i.e. after 30 and 45 days of treatment.

Table No. 17: Statistical analysis on relief of Stabdhata/Jadya [N=43]

\begin{tabular}{|l|l|l|l|l|l|l|l|}
\hline & B T & AT-1 & D-1 & AT-2 & D-2 & AT-3 & D-3 \\
\hline M.G.S. & 10.23 & 10.00 & 0.23 & 6.63 & 3.60 & 3.72 & 6.51 \\
\hline S.D. & \pm 2.662 & \pm 2.887 & \pm 1.065 & \pm 2.829 & \pm 2.518 & \pm 2.462 & \pm 2.324 \\
\hline S.E. & 0.406 & 0.440 & 0.162 & 0.431 & 0.384 & 0.376 & 0.354 \\
\hline t & & & 1.431 & & 9.388 & & 18.377 \\
\hline P & & & $>0.05$ & & $<0.001$ & & $<0.001$ \\
\hline
\end{tabular}


On comparing before and after treatment, the improvement means difference in Stabdhata did not find significant $(\mathrm{P}>0.05)$ effect at first assessment i.e. after 15 days, but found highly significant $(\mathrm{P}<0.001)$ at second and third assessments i.e. after 30 and 45 days of treatment.

Table No. 18: Statistical analysis of relief of Angamarda [N = 50]

\begin{tabular}{|l|l|l|l|l|l|l|l|}
\hline & BT & AT-1 & D-1 & AT-2 & D-2 & AT-3 & D-3 \\
\hline M.G.S. & 8.40 & 7.80 & 0.60 & & 5.70 & 2.70 & 3.42 \\
\hline S.D. & \pm 1.577 & \pm 1.795 & \pm 1.106 & \pm 1.644 & \pm 1.328 & \pm 1.852 & \pm 1.755 \\
\hline S.E. & 0.223 & 0.254 & 0.156 & 0.233 & 0.188 & 0.262 & 0.248 \\
\hline t & & & 3.834 & & 14.369 & & 20.061 \\
\hline P & & & $<0.001$ & & $<0.001$ & & $<0.001$ \\
\hline
\end{tabular}

The symptom Angamarda relief on comparison of mean difference before and after treatments was found highly significant $(\mathrm{P}<0.001)$ from the first assessment on wards to the last assessment.

Table No. 19: Statistical analysis on relief from Alasya $[\mathrm{N}=44]$

\begin{tabular}{|l|l|l|l|l|l|l|l|}
\hline & BT & AT-1 & D-1 & AT-2 & D-2 & AT-3 & D-3 \\
\hline M.G.S. & 7.41 & 7.27 & 0.14 & 5.61 & 1.80 & 3.07 & 4.34 \\
\hline S.D. & \pm 1.575 & \pm 1.468 & \pm 0.632 & \pm 1.434 & \pm 1.564 & \pm 2.463 & \pm 2.034 \\
\hline S.E. & 0.237 & 0.221 & 0.095 & 0.216 & 0.236 & 0.371 & 0.307 \\
\hline t & & & 1.431 & & 7.616 & & 14.157 \\
\hline P & & & $>0.05$ & & $<0.001$ & & $<0.001$ \\
\hline
\end{tabular}

The mean difference in relief of Alasya on comparison before and after treatment was not significant $(\mathrm{P}>0.05)$ at first assessment i.e. after 15 days of the treatment, but found highly significant $(\mathrm{P}<0.001)$ after second and third assessments i.e. after 30 and 45 days of treatment.

Table No. 20: Statistical analysis on improving from Agnimandya $[\mathrm{N}=42]$

\begin{tabular}{|l|l|l|l|l|l|l|l|}
\hline & BT & AT-1 & D-1 & AT-2 & D-2 & AT-3 & D-3 \\
\hline M.G.S. & 2.43 & 2.38 & 0.05 & 1.43 & 1.00 & 0.67 & 1.76 \\
\hline S.D. & \pm 1.016 & \pm 0.936 & \pm 0.309 & \pm 1.063 & \pm 1.036 & \pm 0.477 & \pm 0.692 \\
\hline S.E. & 0.157 & 0.144 & 0.048 & 0.164 & 0.160 & 0.074 & 0.107 \\
\hline t & & & 1.000 & & 6.256 & & 16.507 \\
\hline P & & & $>0.05$ & & $<0.001$ & & $<0.001$ \\
\hline
\end{tabular}

The improvement on Agnimandya was found no significant effect on first assessment ( $\mathrm{P}>0.05)$, but found highly significant $(\mathrm{P}<0.001)$ on second and third assessments of results when the mean difference compared with before and after treatment.

Table No. 21: Statistical analysis on relief of Vidvibandha $[\mathrm{N}=44]$

\begin{tabular}{|l|l|l|l|l|l|l|l|}
\hline & BT & AT-1 & D-1 & AT-2 & D-2 & AT-3 & D-3 \\
\hline M.G.S. & 1.32 & 0.98 & 0.34 & 0.48 & 0.84 & 0.20 & 1.11 \\
\hline S.D. & \pm 0.740 & \pm 0.549 & \pm 0.680 & \pm 0.505 & \pm 0.680 & \pm 0.408 & \pm 0.443 \\
\hline S.E. & 0.112 & 0.083 & 0.103 & 0.076 & 0.103 & 0.062 & 0.067 \\
\hline t & & & 3.325 & & 8.202 & & 16.682 \\
\hline P & & & $<0.01$ & & $<0.001$ & & $<0.001$ \\
\hline
\end{tabular}


The relief in the Vidvibandha was found significant effect $(\mathrm{P}<0.01)$ when compared the mean difference of before and after treatments at first assessment of the results again the highly significant $(\mathrm{P}<0.001)$ was found at second and third assessments of results i.e. after 30 and 45 days of treatment.

Table No. 22: Statistical analysis on reduction of E.S.R [N = 50]

\begin{tabular}{|l|l|l|l|l|l|l|l|}
\hline & B T & AT-1 & D-1 & AT-2 & D-2 & AT-3 & D-3 \\
\hline M.G.S. & 7.20 & 7.20 & 0.00 & 5.00 & 2.20 & 2.92 & 4.28 \\
\hline S.D. & \pm 2.507 & \pm 2.507 & \pm 0.000 & \pm 0.000 & \pm 2.507 & \pm 1.700 & \pm 2.574 \\
\hline S.E. & 0.355 & 0.355 & 0.000 & 0.000 & 0.355 & 0.240 & 0.364 \\
\hline t & & & 0.000 & & 6.205 & & 11.759 \\
\hline P & & & $>0.05$ & & $<0.001$ & & $<0.001$ \\
\hline
\end{tabular}

The reduction of objective parameter E.S.R. levels on comparison with the mean difference before and after treatment was not significant $(\mathrm{P}>0.05)$ at first assessment, but found highly significant reduction levels $(\mathrm{P}<0.001)$ at second and third assessments of the results during 30 and 45 days of the treatment.

Table No. 23: Statistical analysis on reduction of R.A. Factor $[N=50]$

\begin{tabular}{|l|l|l|l|l|l|l|l|}
\hline & BT & AT-1 & D-1 & AT-2 & D-2 & AT-3 & D-3 \\
\hline M.G.S. & 10.00 & 10.00 & 0.00 & 10.00 & 0.00 & 8.06 & 1.94 \\
\hline S.D. & \pm 0.000 & \pm 0.000 & \pm 0.000 & \pm 0.000 & \pm 0.000 & \pm 4.014 & \pm 4.014 \\
\hline S.E. & 0.000 & 0.000 & 0.000 & 0.000 & 0.000 & 0.669 & 0.669 \\
\hline t & & & 0.000 & & 0.000 & & 2.907 \\
\hline P & & & $>0.05$ & & $>0.05$ & & $<0.01$ \\
\hline
\end{tabular}

The objective parameter R.A. factor was not found negatively at first and second assessments of the results. But in very few cases found slightly negative $(P<0.01)$ at the final assessment of the result i.e. after 45 days of the treatment when compared with student's paired ' $t$ ' test on before and after treatment assessments.

$\mathrm{BT}=$ Before Treatment;

$\mathrm{D}-1=\mathrm{BT}-\mathrm{AT}-1$;

$\mathrm{D}-2=\mathrm{BT}-\mathrm{AT}-2$

$\mathrm{D}-3=\mathrm{BT}-\mathrm{AT}-3$;

S.D. $=$ Standard Deviation ;

' $\mathrm{t}$ ' = Students Paired ' $\mathrm{t}$ ' test;

\section{Discussion:}

It was observed as per Age and Sex a maximum of $34 \%$ of patients were from 31- 40 years age group, as per the occupation a maximum of $36 \%$ were house wives, $24 \%$ were Labour while $20 \%$ were businessman.

As per the relief in Subjective parameters $50 \%$ were in moderate relief group, while $48 \%$ were of mild relief and there was good relief in $2 \%$ of patients.

In Objective parameter ESR, complete improvement was seen in $26 \%$ of patients,
AT-1 = After 15 days Treatment;

AT-2 = After 30 days Treatment;

AT-3 = After 45 days Treatment;

M.G.S. = Mean Grade Score;

S.E. = Standard Error;

$\mathrm{P} \quad=$ Probability

moderate improvement was observed in $30 \%$ of patients, mild improvement was observed in $22 \%$ of patients, while there was no improvement in $22 \%$ of patients.

In Objective parameter Sandhi Shotha, Good response was observed in $16 \%$ of patients, Moderate response was observed in $34 \%$ of patients, Mild response was observed in $22 \%$ of patients, while there was no improvement in $12 \%$ of patients.

By considering RA factor, it was static in $58 \%$ of the patients, i.e., positive before and after treatment, $28 \%$ negative 
before and after treatment, while $14 \%$ of patients shown negative RA factor after the complete course of the treatment.

As per the percentage of relief of symptoms, the basis of the total score before and after treatment, Vidvibandha was the highest percent relief that is $84 \%$, followed by $72 \%$ Agnimandya, 63\% Jadya, $60 \%$ in ESR, $58 \%$ in Alasya, $56 \%$ in Sandhi Shotha, 46\% in Sandhi Shula and $20 \%$ in RA factor.

As per statistical analysis on overall parameters, treatment is found highly significant as per the Sandhi Shula, Stabdhata, Angamarda, Alasya, Agnimandya, and Vidvibandha. Reduction of Sandhi Shotha, ESR and reduction of RA factor were also seemed to be highly significant for the effect of drug.

\section{Conclusion:}

In Clinical study 50 patients were selected and trial drug was advocated in a dose of $300 \mathrm{mg}$. (2 tablets) twice a day with Trikatu and Arka moola twak kashaya as anupana. Treatment was given for 45 days with the result assessment recorded at every 15 days. Subjective and objective parameters were analyzed before and after the treatment.

In subjective parameters Sandhi Shula, Sandhi Shotha, Jadya, Angamarda Alasya, Agnimandhya and Vidvibandha are considered, while both Erythrocyte Sedimentation Rate (ESR) and R.A. Factor were considered as objective parameters. It was observed that $48 \%$ were in mild relief group, while $50 \%$ were of moderate relief and there was Good relief in $2 \%$ of patients.

Both Subjective and Objective parameters have been analyzed statistically. The relief of Sandhi Shula, Sandhi Shotha, Stabdata, Angimandya, Angamarda, Alasya and Vidvibandha found highly significant $(\mathrm{P}<0.001)$ and same results in reduction of ESR levels and RA Factor. Hence it can be concluded that Panchavaktra Ras prepared as per the textual standards is highly effective in Amavata and showing a way out to the individual suffering from this chronic disease.

\section{References:}

1. Himasagara Chandra Murthy P. (ed.), Madhavanidhanam of Sri

Madhavakara, Choukhamba Sanskrit Series Offfice, Varanasi; 2006; 272p

2. Ibid; 273p

3. Pandita Kashinath Shastry, RasaRasa Tarangini by Pranacharya Sri Sadananda Sharma, Motilal Banarasidas, New Delhi. Reprint: 2004; 81p

4. Ibid: $177 \mathrm{p}$

5. Ibid: $318 \mathrm{p}$

6. Puvvada Suryanarayana, Basavarajeeyam, by Basava Raju, ABS Publishers, Rajahmundry, 1998 (telugu); 309p 
Figure no 1: Soft tissue swelling before and after the treatment in Ankle joint

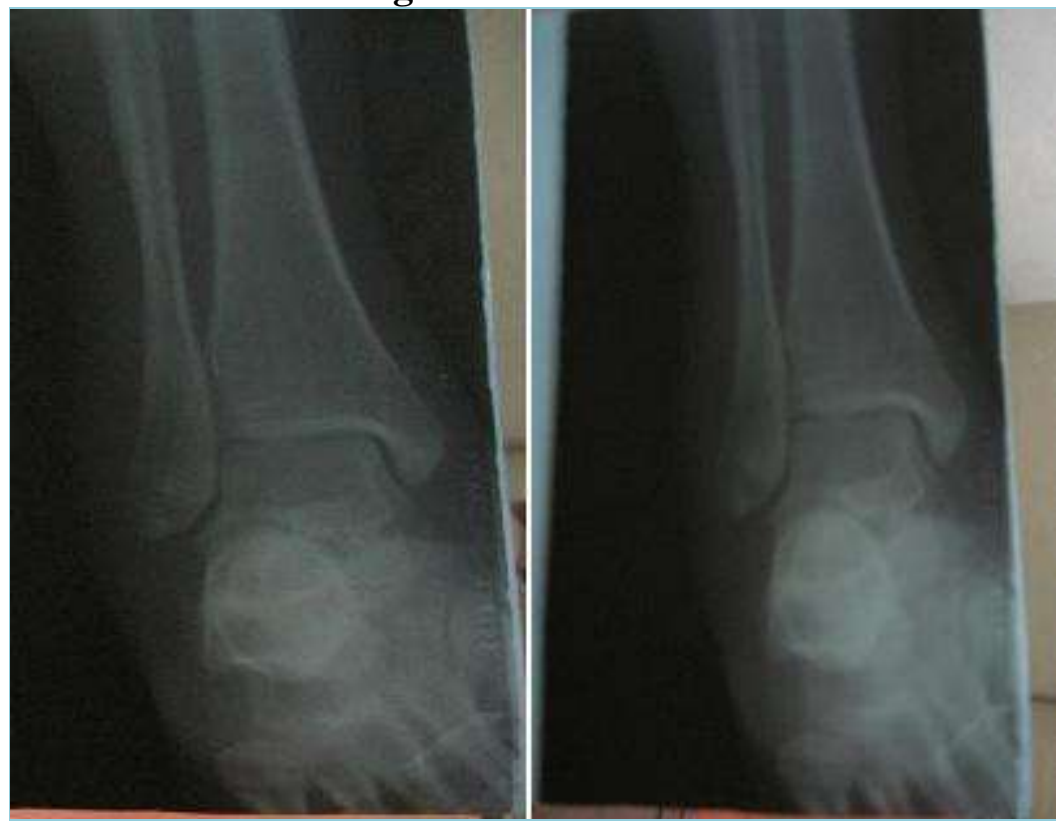

Figure no 2: Swelling before and after the treatment in knee joints

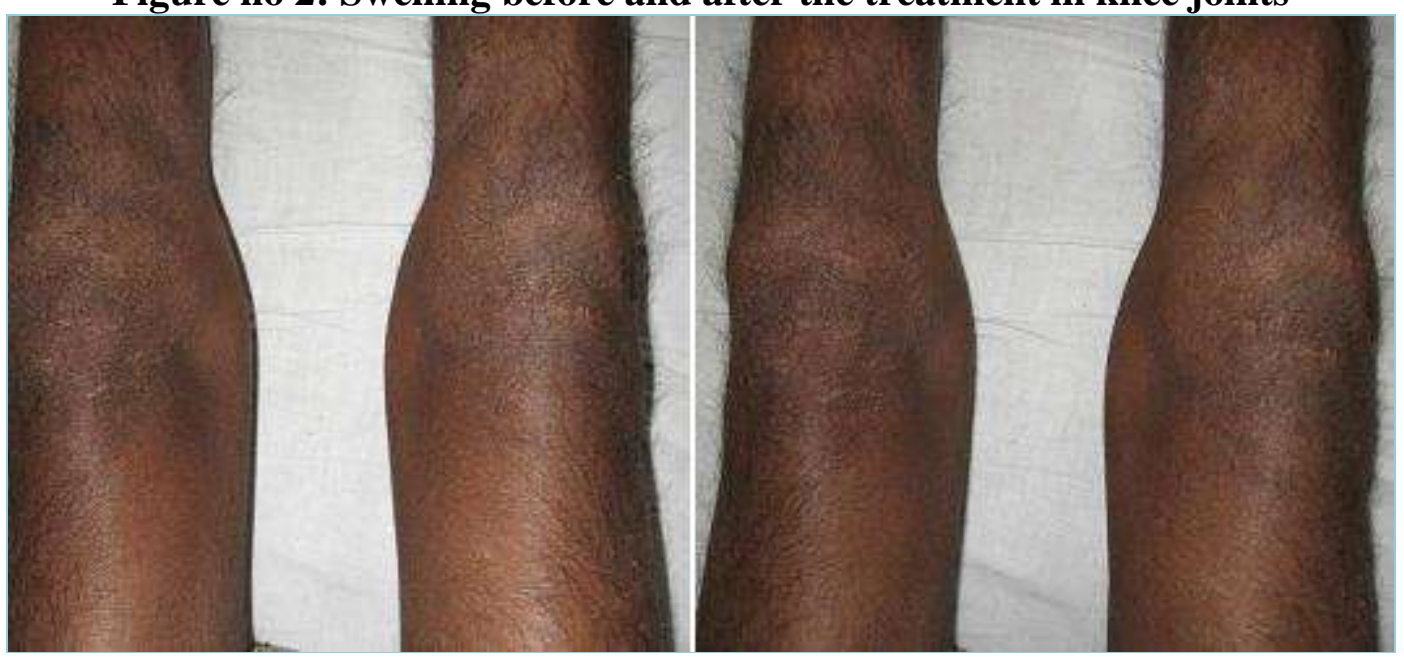

Figure no 3: Soft tissue swelling before and after the treatment in knee joint

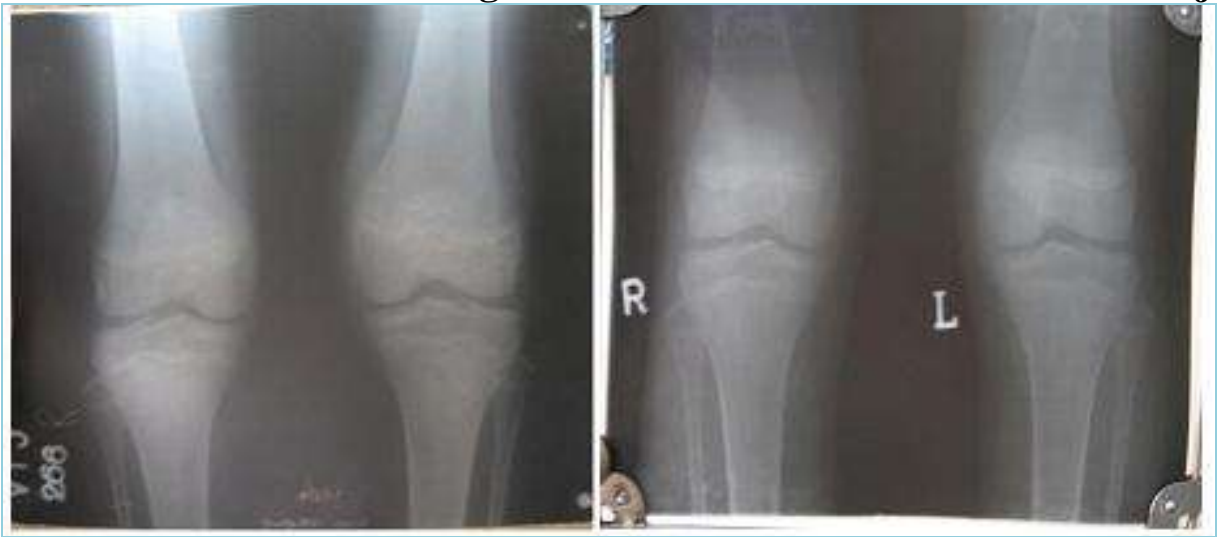


Figure no 4: Preparation of Panchavaktra ras

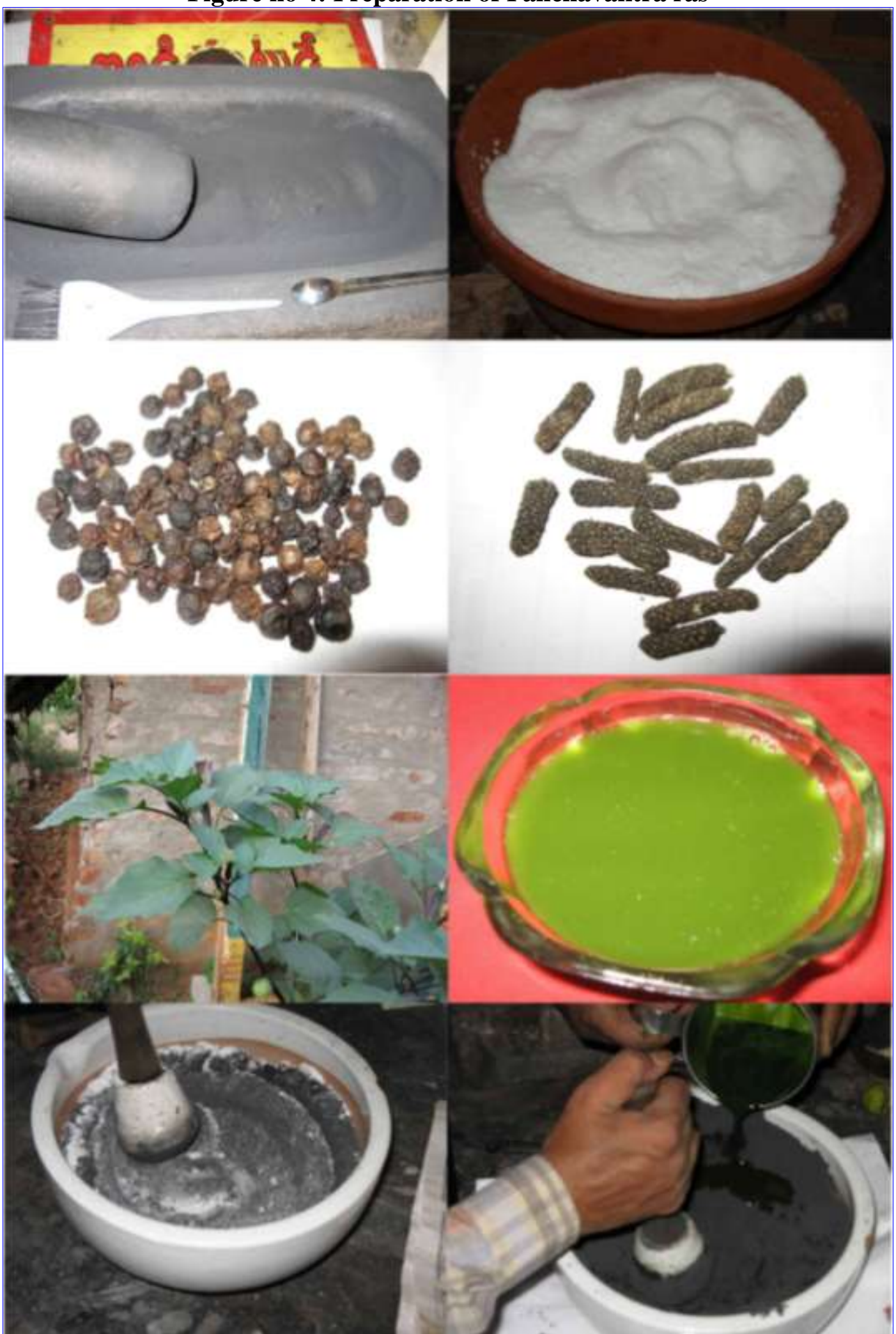


Figure no 5: Contd.... of preparation of Panchavaktra ras

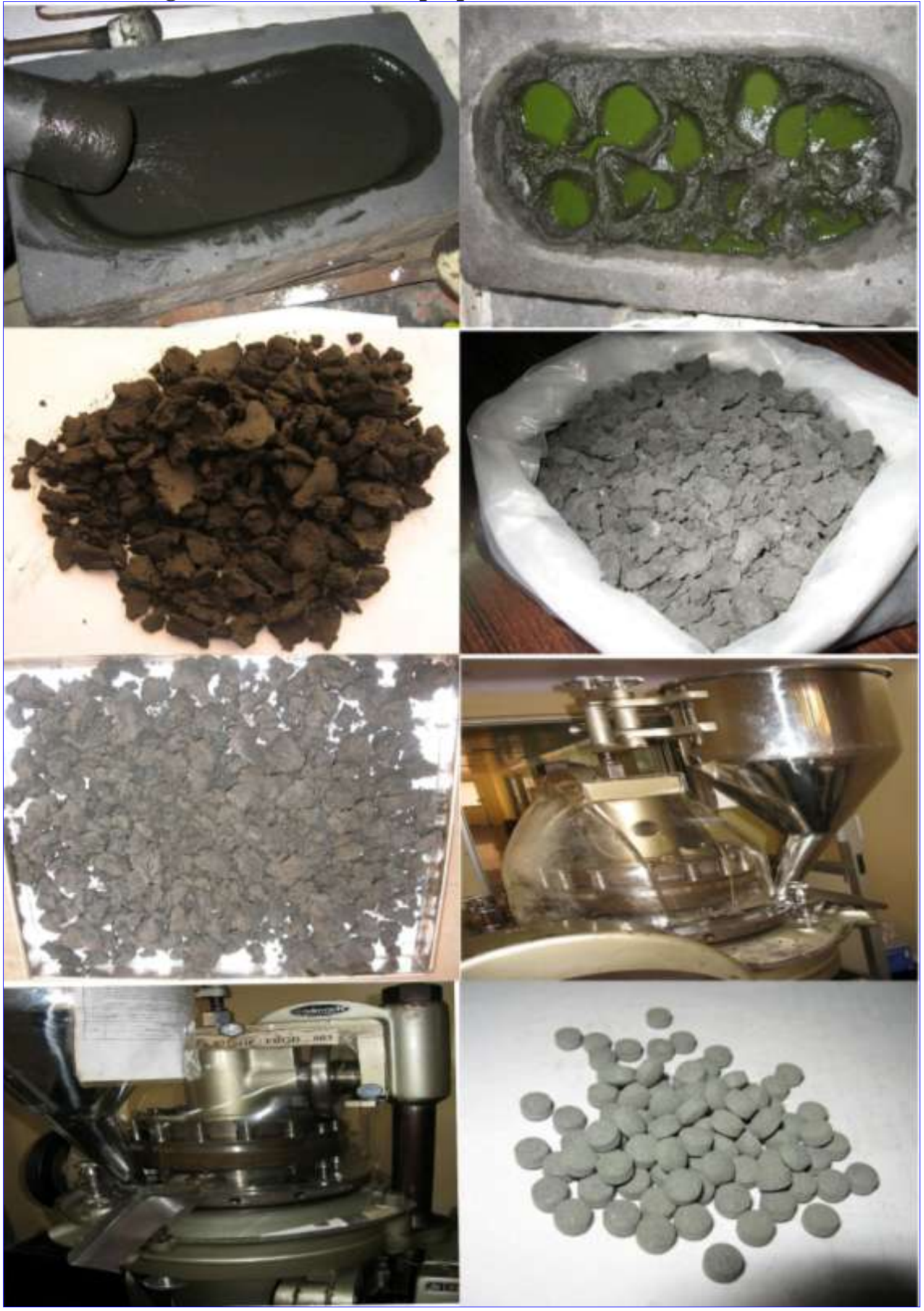


Bio Statistical Graphs:

Graph no 1: relief in Sandhi Shula $(N=50)$

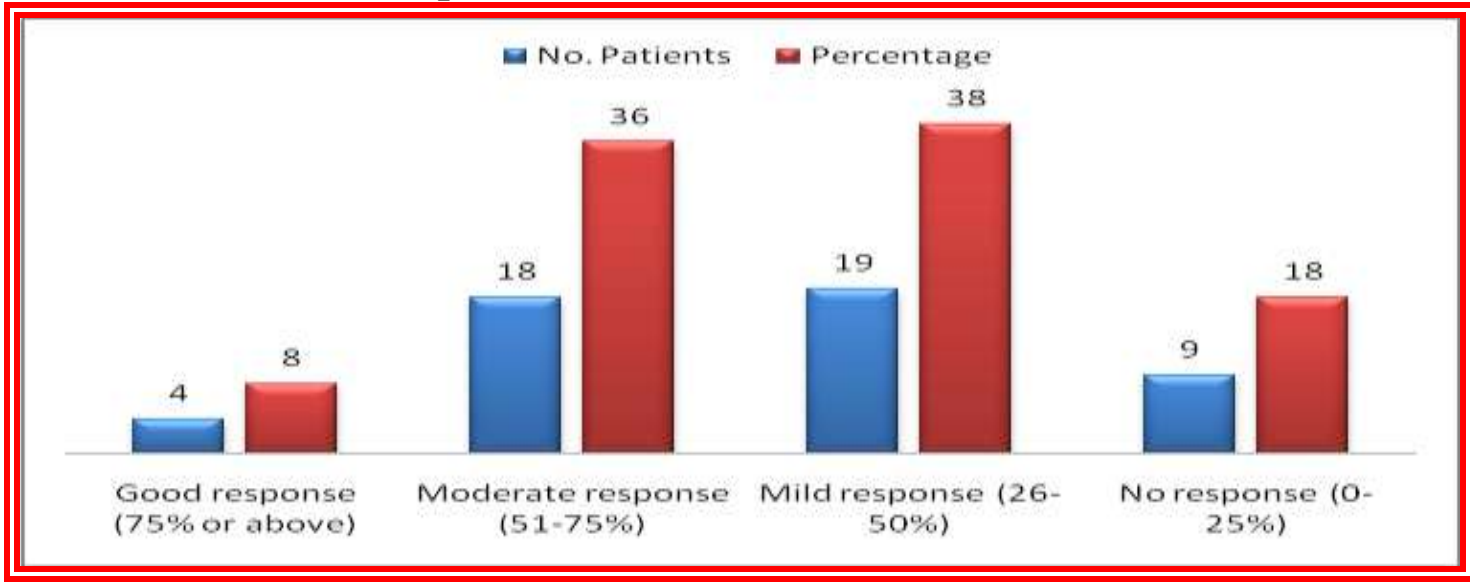

Graph no 2: relief in Jadya (N=43)

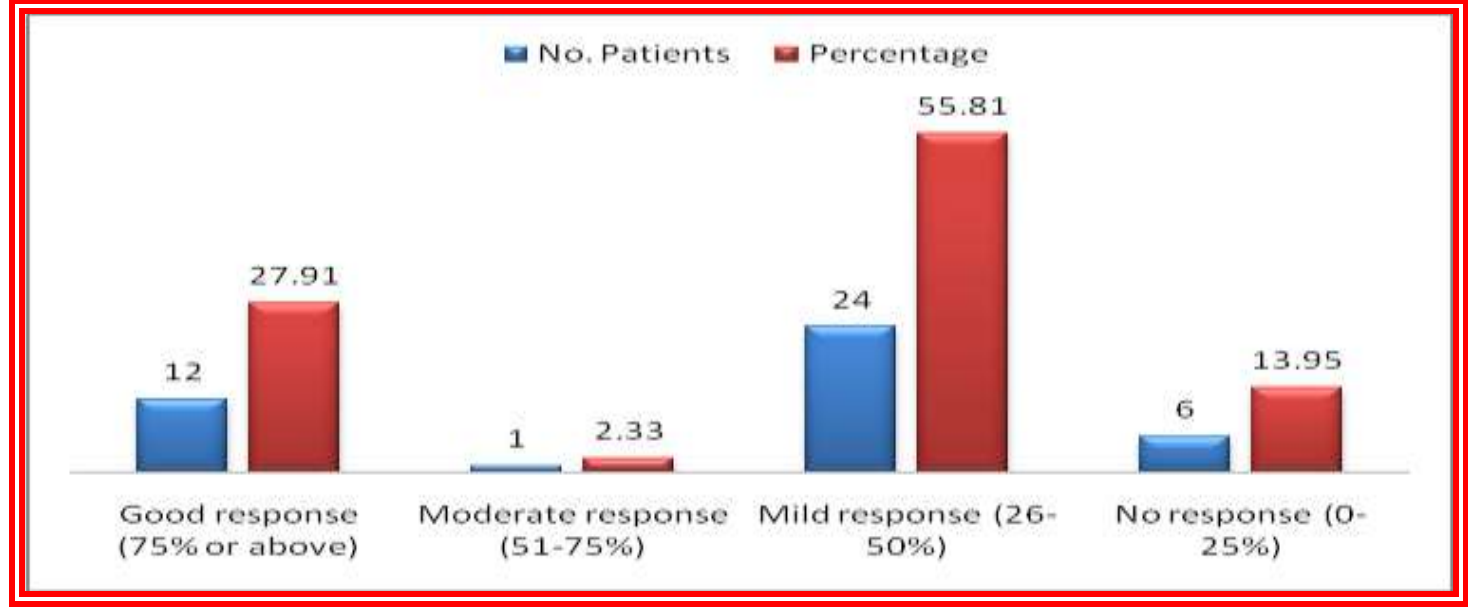

Graph no 3: relief in Angamarda $(\mathrm{N}=50)$

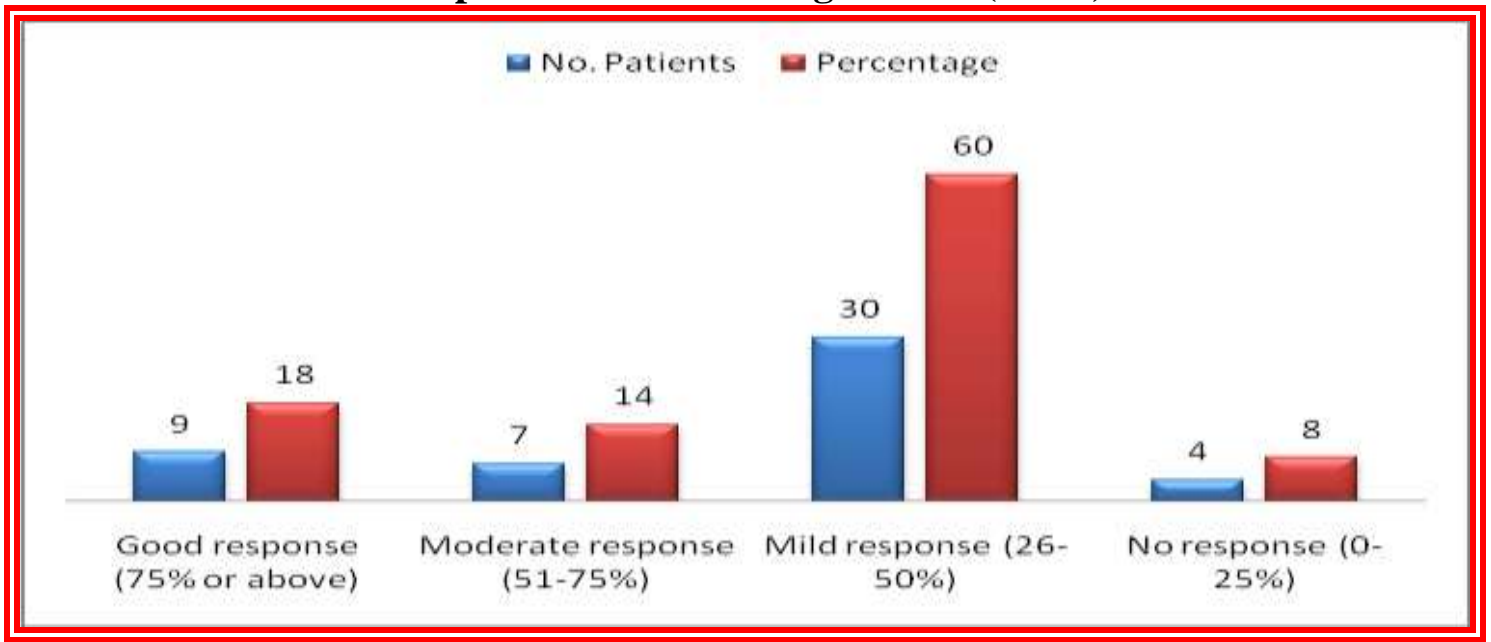


Graph no 4: relief in Alasya $(N=44)$

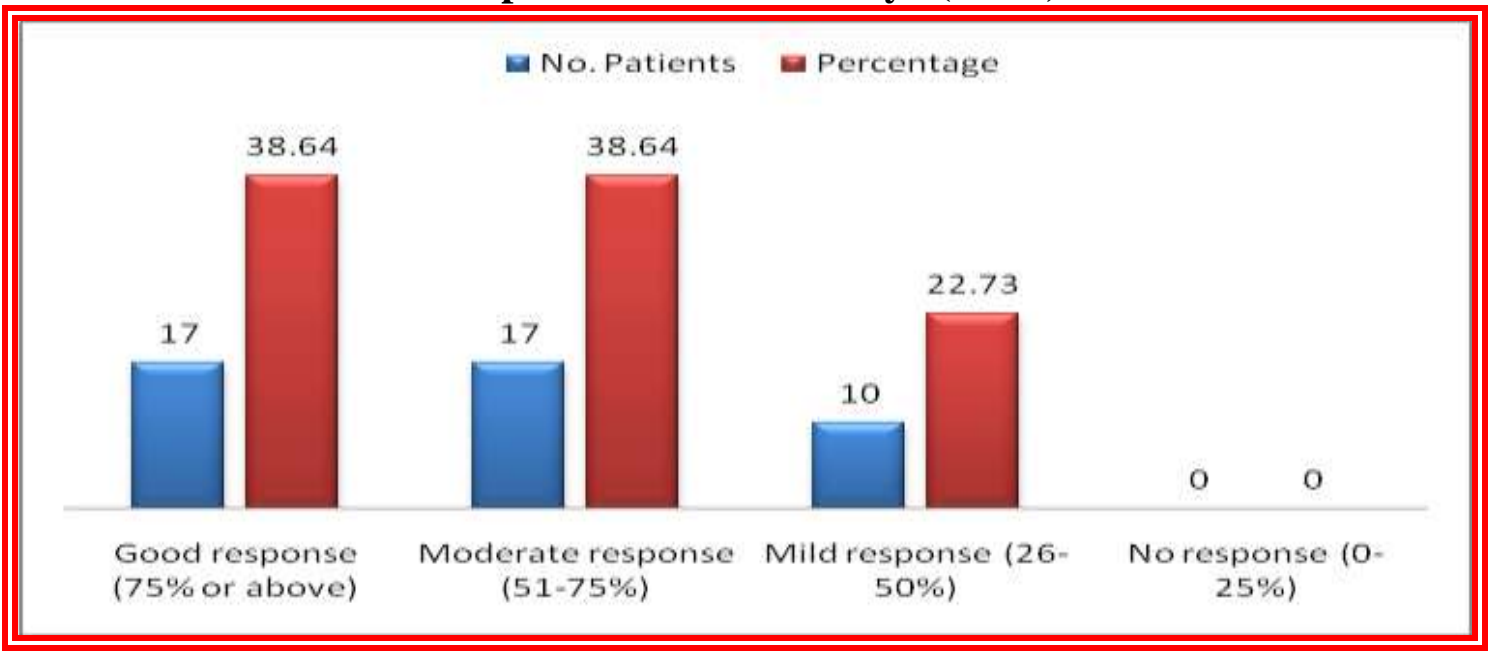

Graph no 5: relief in Agnimandya ( $N=42)$

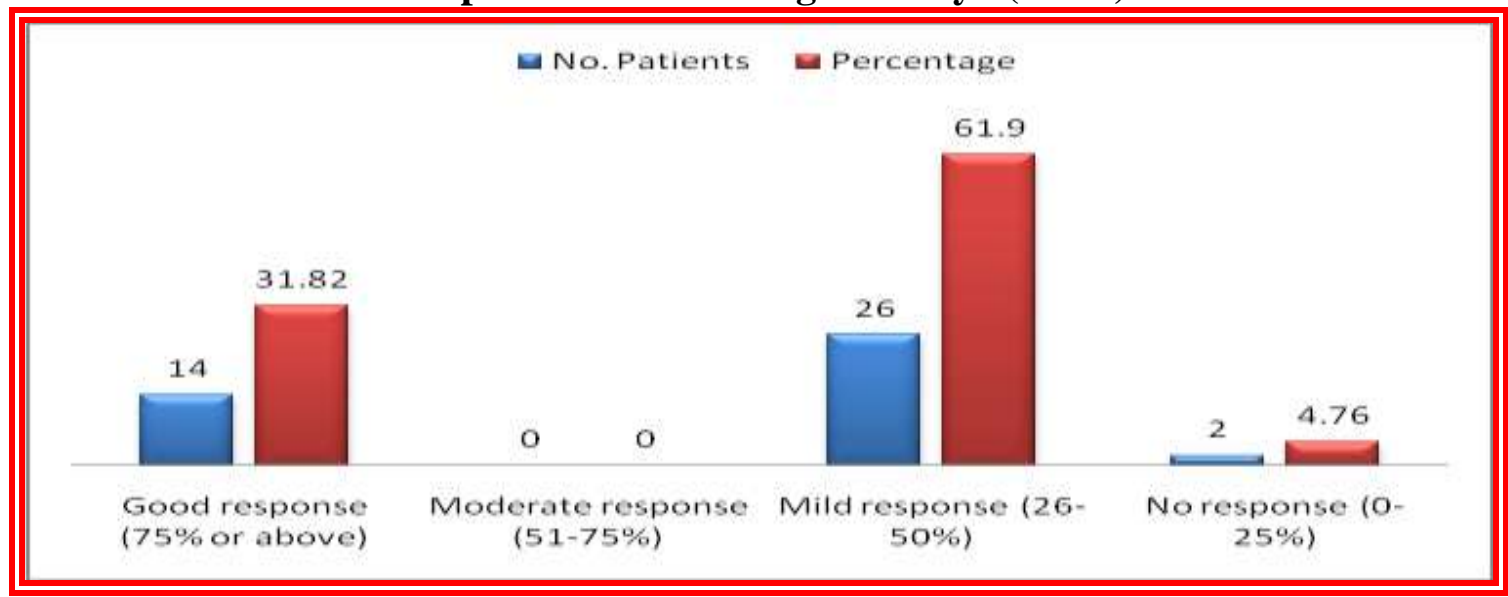

Graph no 6: relief in Vidvibandha $(N=44)$

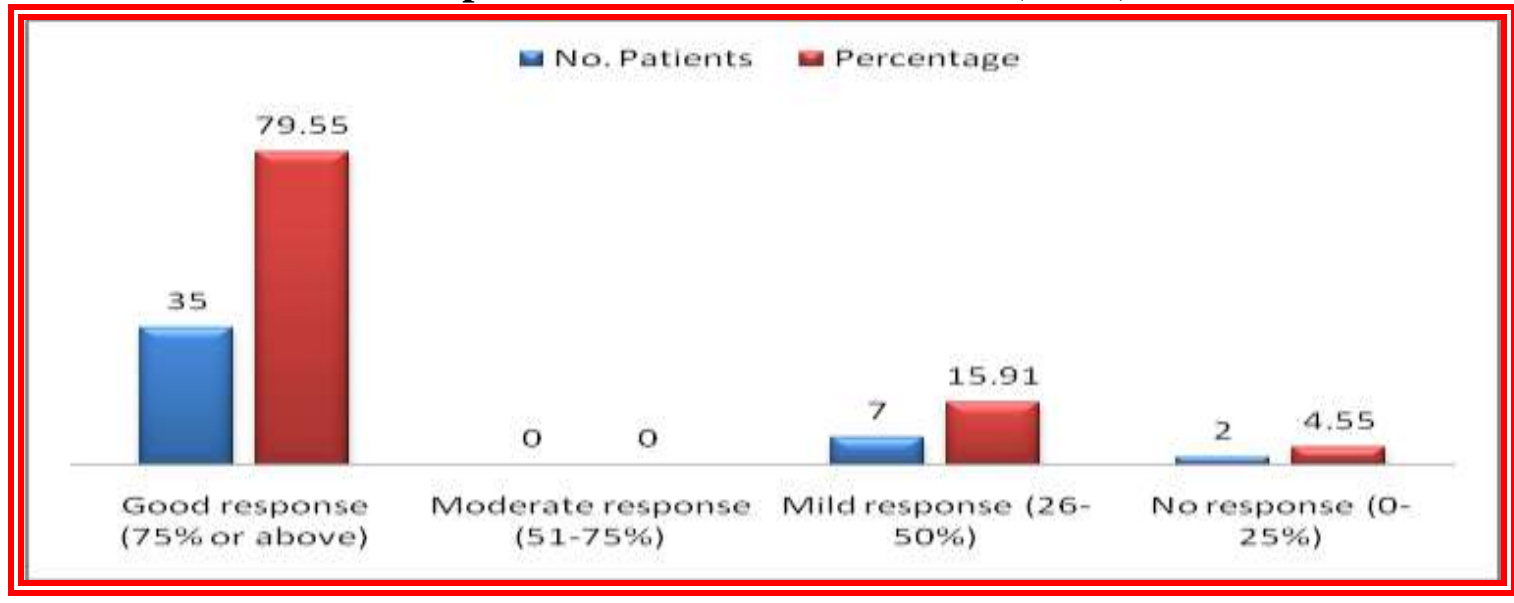


Graph no 7: results in Sandhi Shotha $(N=45)$

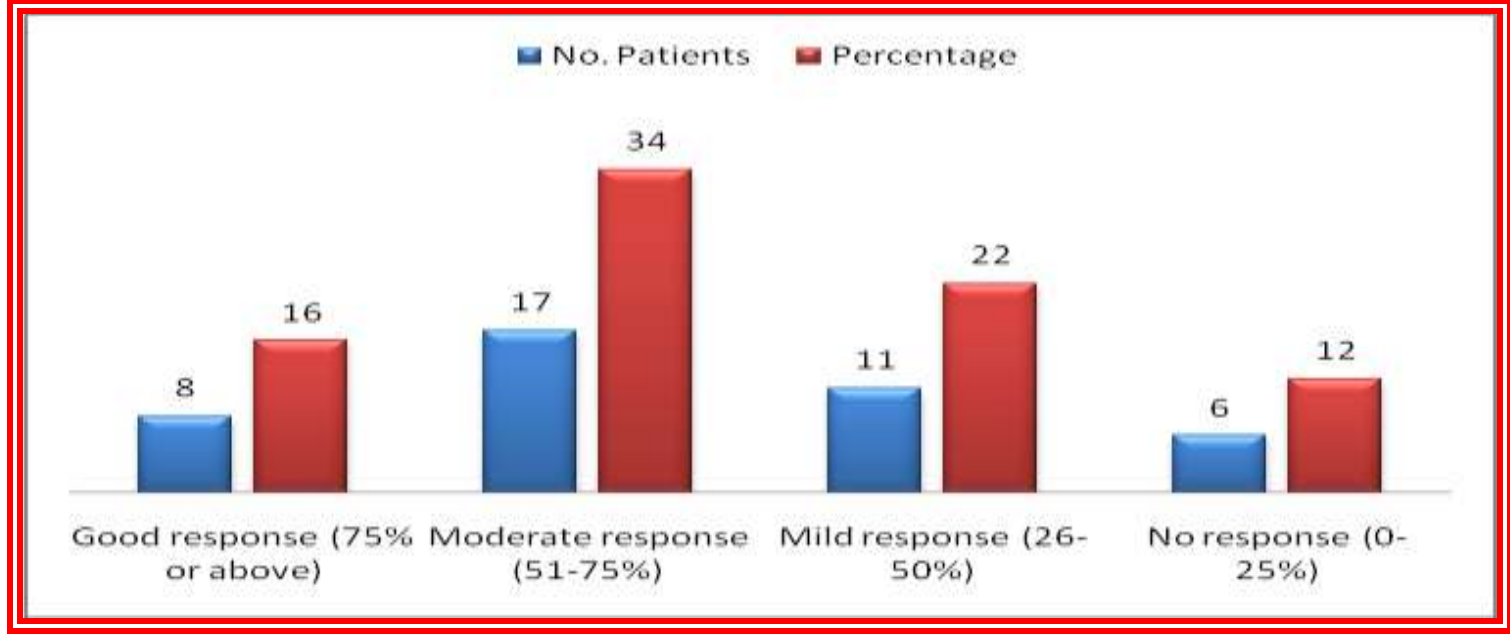

Graph no 8: results in E.S.R $(\mathbf{N}=50)$

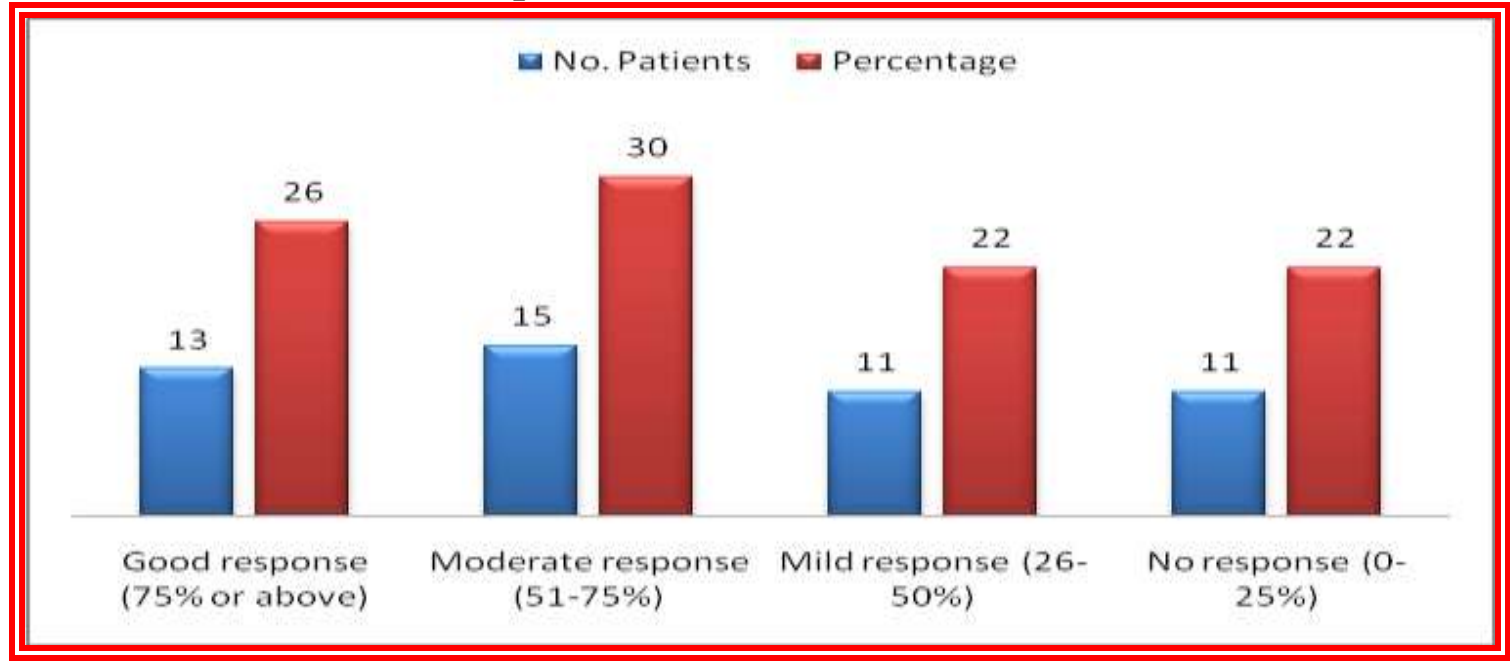

Graph no 9: results in R.A Factor $(\mathrm{N}=50)$

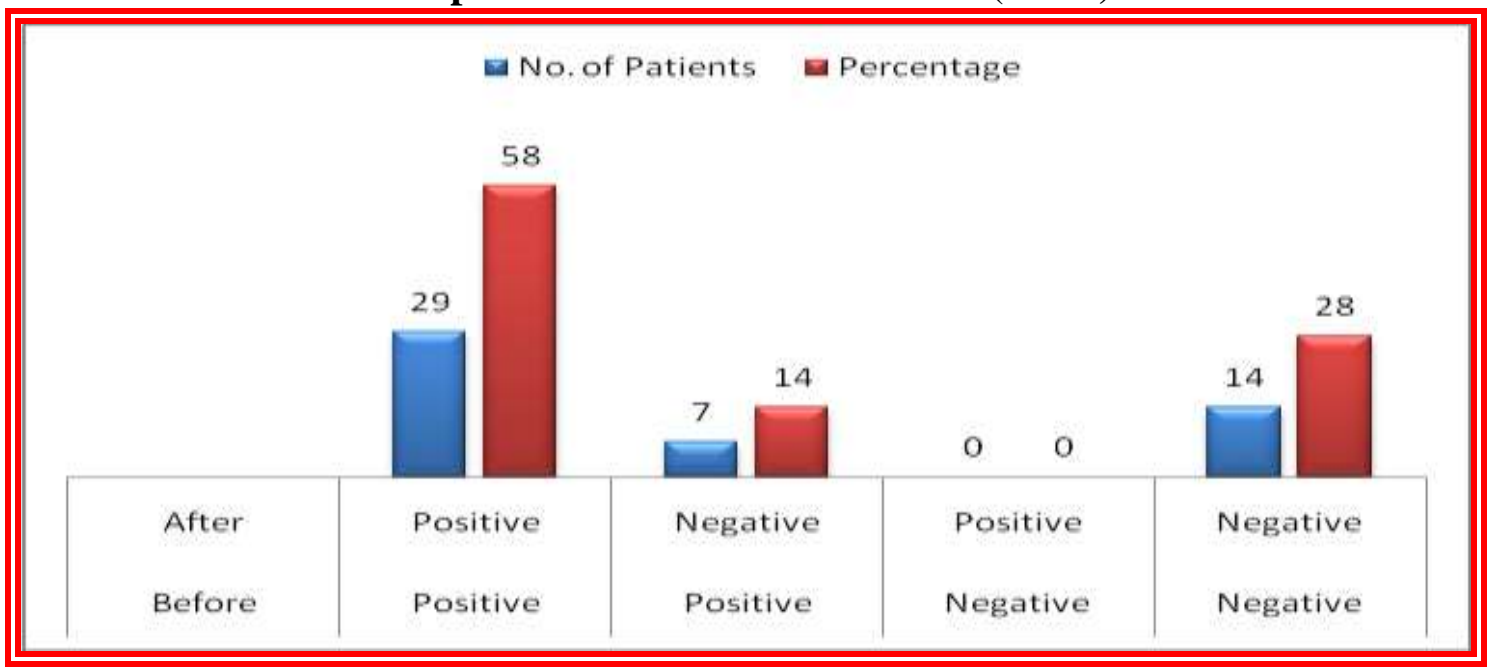




\section{Graph no 10: Symptoms wise observation}

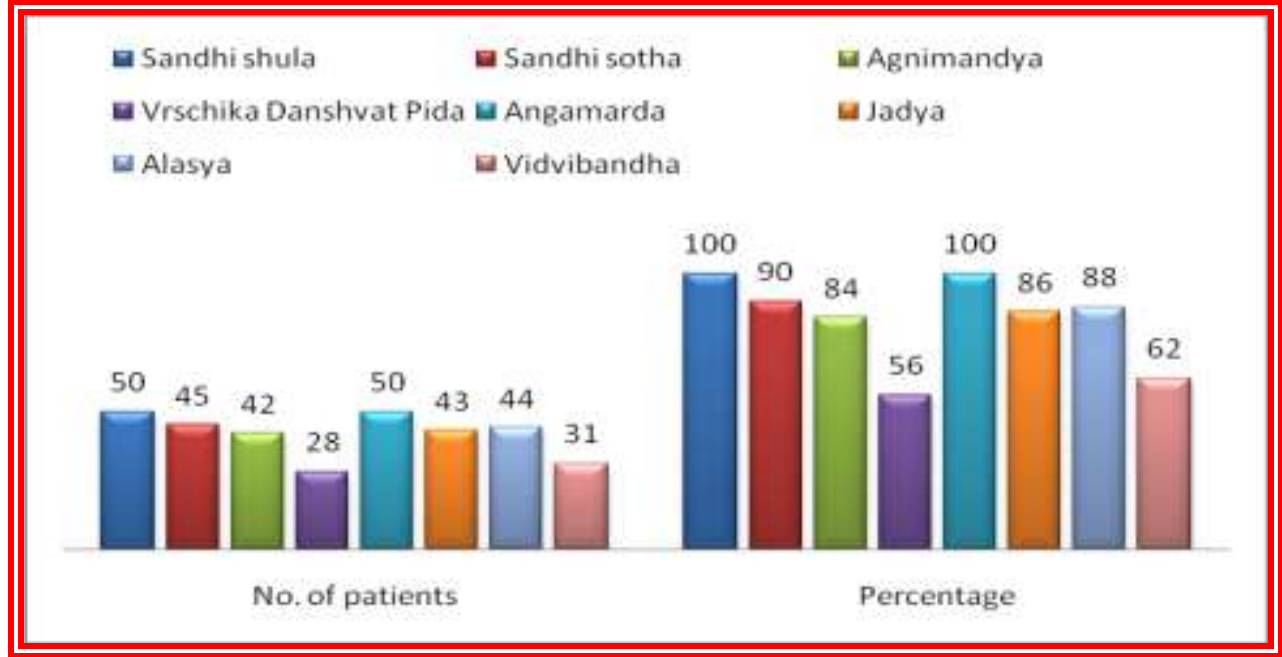

Graph no 11: Results in all subjective parameters

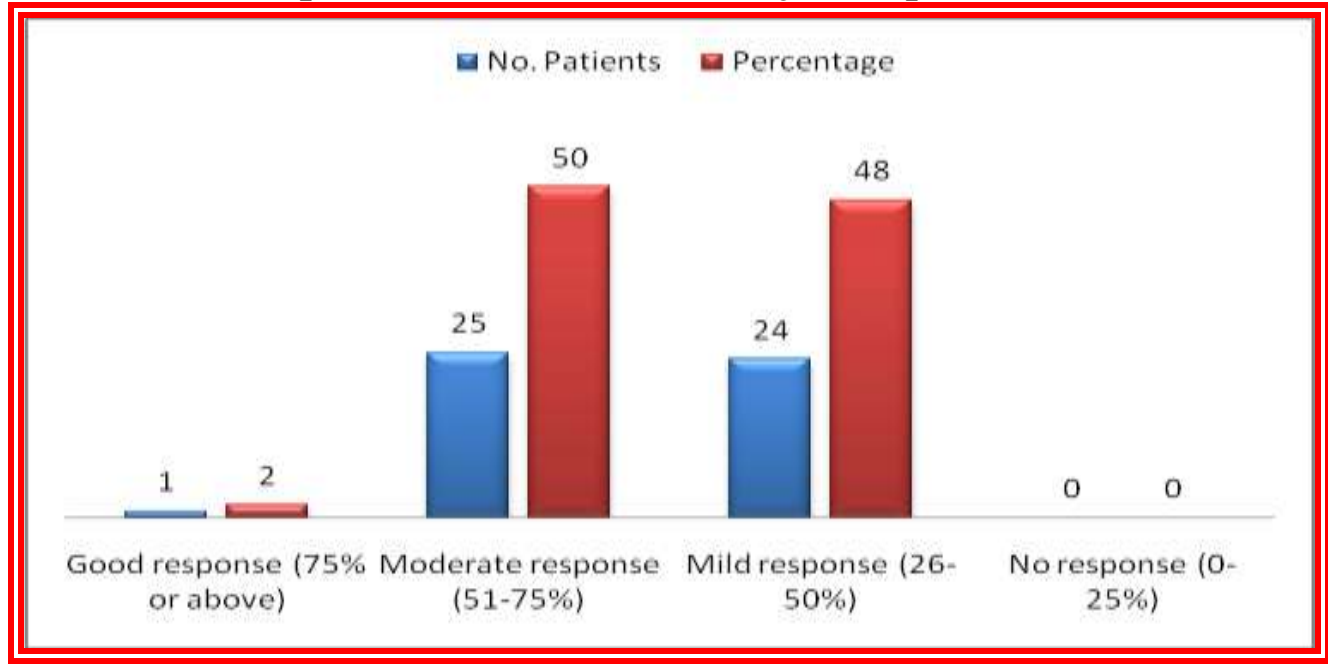

Graph no 12: Percentage of relief in Amavata

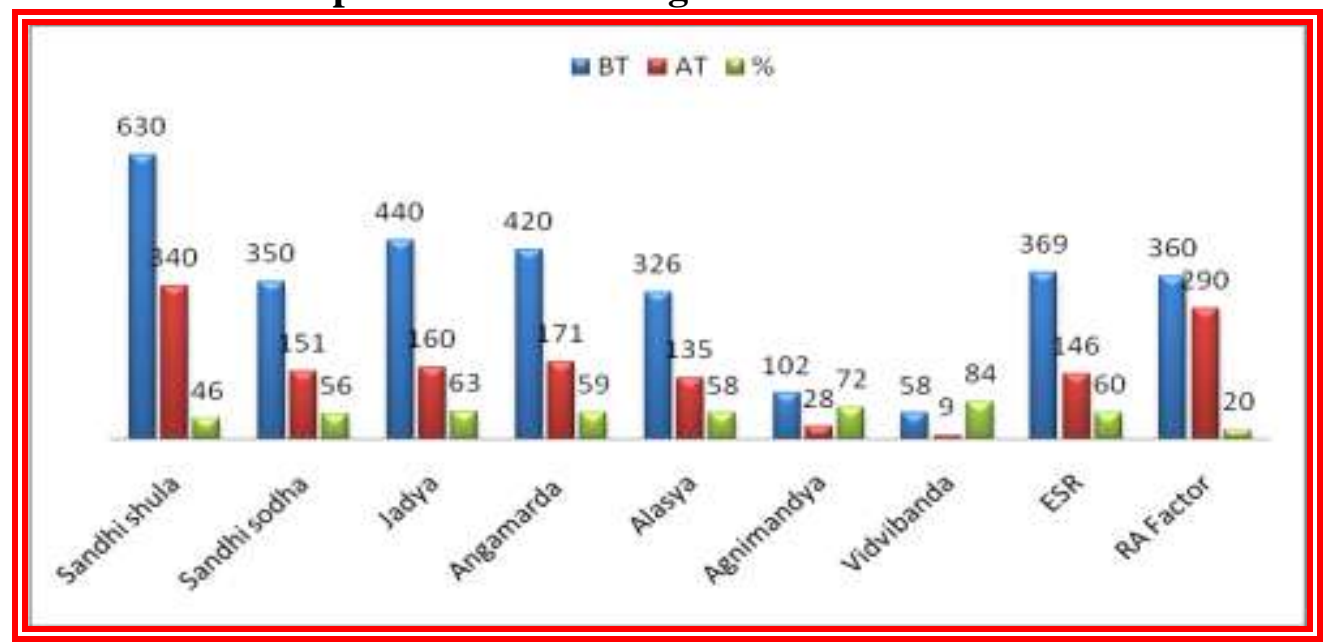

$* * * * * *$ 